\title{
Groundwater Assessment: A Case Study in Patna and Gaya District of Bihar, India
}

\author{
Amit Kumar ${ }^{1 *}$, Shikha Anand ${ }^{2}$, Manish Kumar ${ }^{2}$ and Ravish Chandra ${ }^{3}$ \\ ${ }^{1}$ M.P.U.A.T, Udaipur, Rajasthan-313001, India \\ ${ }^{2}$ G.B. Pant University of Agriculture and Technology, Pantnagar, Uttrakhand- 263145 \\ ${ }^{3}$ Dr. R.P.C.A.U., Pusa, Bihar-848125, India \\ *Corresponding author
}

\section{Keywords \\ Ground water, Patna and Gaya district, GEC-97, Water level fluctuation techniques.}

Article Info

Accepted:

04 October 2017

Available Online:

10 December 2017

\section{A B S T R A C T}

Assessment of groundwater is an effective tool for proper planned and optimal utilisation of water resources in the context of future national requirement and expected impact of climate changed, its variability is critical for relevant national and regional long term development strategies and sustainable development. Our main purpose for the assessment of groundwater in Patna and Gaya district is to compute a complete evaluation of groundwater resources and produce information that can be incorporated for future requirement.The study was undertaken based on the recommendation of groundwater estimation committee, 1997 (GEC-97). Methodology used the estimation of annual groundwater recharge from rainfall and other sources, including irrigation, water bodies and artificial recharge, determination of present status of groundwater utilization and categorization of assessment units based on the level of groundwater utilization and longterm water level trend. Water level fluctuation techniques and empirical norms were used for recharge estimation. The data collected for investigation were water table fluctuation data, rainfall data cropping pattern, number of groundwater structures, hydrogeology of area, specific yield, groundwater draft, pond area etc. The study computes the following result for Patna District and Gaya District respectively. Total annual groundwater recharge is 91924.33 ha-m and 98648.29 ha-m, net annual replenishable groundwater resource is 82731.93 ha-m and 88783.47 ha-m, groundwater draft for all uses is 47328.6 ha-m and $43140.2 \mathrm{ha}-\mathrm{m}$. The net annual groundwater available for future irrigation development is 35403.325 ha-m and 45643.27 ha-m. The stage of groundwater development is $57.20 \%$ and $48.59 \%$ which falls in safe category for both. The study recommended that there is a good scope for future groundwater development and keeping in view of rapid increase in groundwater draft, roof top rainwater harvesting needs to be taken up to recharge the aquifer in Patna and Gaya district particularly in urban areas.

\section{Introduction}

Groundwater, which is $38.5 \%$ of the available water sources of the country, plays a major role in irrigation, rural and urban drinking water supply and industrial development. Groundwater meets nearly 55 $\%$ irrigation, $85 \%$ of rural and $50 \%$ of urban and industrial needs (Government of India,
2007). Groundwater resources are under increasing pressure caused over-exploitation of groundwater for meeting the rising demand from agriculture and rapid growth in urbanization and industrialization. Overexploitation of groundwater leads to: reduction in water yield in the wells, increase 
in pumping depth and cost of pumping, contamination of groundwater and most importantly, in the failure of wells causing heavy economic losses to the farmers.

Access to groundwater can be a major engine for food security, poverty alleviation and economic development in the rural areas. The effective management and utilization of groundwater not only as a source of water for agriculture and other consumptive purposes, but also as a supplementary source of surface water flows, wetlands and wildlife habitats. The ground water management is the major challenge facing the water resources because once it modified and contaminated, ground water can be very costly and difficult to restore.

Ground water remains the life line of socioeconomic development in the Ganga alluvial plain (GAP) since the dawn of civilization in the Indian subcontinent. The quaternary sequence forming top layer of the thick unconsolidated sediments of the GAP, holds nearly $30 \%$ of the total annual replenishable ground water resources of India (Govt. of India, 2006). Increasing groundwater extraction from GAP has resulted in surfacing of aquifer stress symptoms like lowering of ground water levelled and ground water quality deterioration (World Banks, 1998).A recent assessment in the three states of North and East India, viz. U.P., Bihar and West Bengal covering nearly $80 \%$ of GAP, identified 37 community development blocks (Ground water resource assessment unit) under over exploited Category. Ground water extraction has exceeded the annual replenishable resource (Govt. of India, 2006). A planned approach is therefore essential for sustainable development of this precious natural resource as dependence on ground water is likely to increase in future. For this the first task would be to make a realistic assessment of ground water resources and the plan their use in such a way that full crop water requirement are met and there is neither water logging nor excessive water lowering of ground water table. It is necessary to maintain the ground water reservoir in a state of dynamic equilibrium over a period of time and the water level fluctuations have to be kept within a particular range over the monsoon and non-monsoon seasons.

The Bihar state forms a part of mid-Ganga plain. About $33 \%$ of the geographical area of the state in the south of the Ganga River is covered by alluvial deposits often referred to as marginal alluvial plain. Bihar is becoming very important state for pushing agriculture production of the country. The stage of ground water development in the state is only $39 \%$. In light of the above mentioned points this study is taken up to assess the ground water situation of Patna and Gaya district which is located in south of Bihar.

\section{Materials and Methods}

The methodology used for ground water resource assessment is based on the recommendation of ground water estimation committee, 1997 (GEC-97). The basic principle followed in this methodology is the estimation of annual groundwater recharge from rainfall and other sources, including irrigation, water bodies and artificial recharge, determination of present status of groundwater utilization and categorization of assessment units based on the level of groundwater utilization and long-term water level trend. These estimations are widely used in formulating various groundwater development and management plans.

\section{Study area}

The Patna and Gaya district of Bihar were selected as the study area for investigation. Patna district is surrounded by two river 
system namely Ganga in the North and Sone in the West. The geographical area of district is 317236 ha with $4.13 \%$ land not suitable for cultivation. Administratively the district is divided into 6 subdivisions, 23 blocks, 344 panchayat and 1433 villages.

Gaya is $100 \mathrm{~km}$ south of Patna and is situated on the bank of Falgue River. It is surrounded by small rocky hills by three sides and the river flowing on the fourth (western) side. The geographical area of Gaya district is 497600 ha. Administratively the district is divided into 4 subdivisions, 24 blocks and 2860 villages

\section{Physiography and soils}

Patna and Gaya district is situated in the south Bihar alluvial plains (Zone III B) of divided Bihar. This zone is located in south of river Ganga. The Patna district has mainly four types of soil ranging from moderately well drain to poorly drain, acidic to slightly alkaline and medium to heavy texture while Gaya district consists mainly calcareous alluvial soil. It is deficient in nitrogen, phosphoric acid and humus texturally the soils are sandy to loam and the ph value is on the alkaline side.

\section{Climate}

The average normal rainfall of Patna district is $970.53 \mathrm{~mm}$ out of this $818.12 \mathrm{~mm}$ in monsoon season and $152.41 \mathrm{~mm}$ in nonmonsoon season and average normal rainfall of Gaya district is $961.83 \mathrm{~mm}$ out of this 847.4 $\mathrm{mm}$ in monsoon season and $114.43 \mathrm{~mm}$ in non-monsoon season.

\section{Hydrogeology}

Ground water sources of irrigation depend on groundwater recharging and alluvial deposits. Patna district comes under the porous formations. The Quaternary alluvial deposits spread over the area. The thickness of the alluvial deposit ranges to a maximum of 700 $\mathrm{m}$.

The Gaya district comes under the fissured formation with Quaternary alluvial, Precambrian granite gneiss rock formation.

The occurrence and movement of ground water in this unit is controlled by the thickness and nature of weathered residuum besides presence of fractures in the rock.

\section{Irrigation structures}

There are 4971 dug wells, 27930 shallow tube wells and 308 deep tube wells in Patna district. Similarly for Gaya district there are 17882 numbers of dug wells, 24810 numbers of shallow tube wells and 59 deep tube wells.

\section{Cropping pattern}

Cultivation is practice in all three cropping seasons i.e. rabi $(66.62 \%)$, kharif $(57.8 \%)$ and summer $(2.38 \%)$ in its net cultivated area. The main crops of Patna district are wheat, paddy, maize, mustard, sunflower, chickpea, arhar and vegetables.

Agriculture is main occupation of Gaya district. Cultivation is in practice in all three cropping season. The main crops of Gaya district are paddy, wheat, potato, lentils, sorghum, millet, cowpea, ground nut.

\section{Specific yield}

It is defined as the actual volume of water that can be extracted by the force of gravity from a unit volume of aquifer material is known as the specific yield. It is expressed as

$\mathrm{S}_{\mathrm{y}}=\frac{V_{d}}{v} \times 100$ 
Where, $V_{d}$ is the volume of water that can be extracted by the force of gravity and $\mathrm{v}$ is the total volume. The value of specific yield for Patna and Gaya districts is taken as 0.10

\section{Ground water draft}

The amount of ground water extracted from the ground resources with the help of pumping unit is called ground water draft. The gross ground water draft would include the ground water extraction from all existing ground water structures.

The ground water draft can be calculated by the number of wells of different types multiplied by unit draft. The no. of ground water structures is based on last minor irrigation census (2000-01). Norms for ground water draft for Bihar state as per GEC-norms 97 are for dug wells it is 0.6,for shallow tube wells 1.0 and for deep tube wells it is 30.0 .

\section{Recharge from return flow from ground water irrigation}

Recharge from return flow from ground water irrigation is considered to be as per GEC-97 norms.

\section{Recharge from ponds}

It is taken as $1.4 \mathrm{~mm} /$ day for the period in which the pond has water, based on the average area of water spread as per GEC-97 norms.

$\mathrm{R}_{\mathrm{t}}=$ Pond area $\times 1.4 \frac{\mathrm{mm}}{\text { day }} \times($ No.of days $)$

\section{Methodology}

The present methodology used for resource assessment is known as ground water resource estimation methodology-1997 (GEC-
97). Two approaches recommended are Water level fluctuation method and Rain infiltration method.

\section{Ground water recharge}

\section{Monsoon season}

The recharge assessment during monsoon season is made as the sum total of the change in storage and gross draft. The change in storage is computed by multiplying water level fluctuation between pre and post monsoon periods with the area of assessment and specific yield. Monsoon recharge can be expressed as

$\mathrm{R}=\mathrm{S}+\mathrm{DG}=\mathrm{h} \times \mathrm{S}_{\mathrm{y}} \times \mathrm{A}+\mathrm{DG}(1)$

Where, $\mathrm{R}$ is the recharge during monsoon, $\mathrm{S}$ is the change in storage, DG is the gross draft during monsoon season, $\mathrm{h}$ is the rise in water table during monsoon season, $\mathrm{S}_{\mathrm{y}}$ is the specific yield and $\mathrm{A}$ is the area of assessment.

The monsoon ground water recharge has two component-rainfall recharge and recharge from other sources.

The recharge calculated from equation (1) gives the available recharge from rainfall and other sources for the particular monsoon season. The recharge from rainfall is given by,

$\mathrm{R}_{\mathrm{rf}}=\mathrm{R}-\mathrm{R}_{\mathrm{gw}}-\mathrm{R}_{\mathrm{wc}}-\mathrm{R}_{\mathrm{t}}$

Hence,

$R_{r f}=h \times S_{y} \times A+D G-R_{g w}-R_{w c}-R_{t}(2)$

Where, $\mathrm{R}_{\mathrm{rf}}$ is the recharge from rainfall, $\mathrm{R}_{\mathrm{gw}}$ is the recharge from groundwater irrigation in the area, $R_{w c}$ is the recharge from water conservation structures and $R_{t}$ is the recharge from ponds. 
The recharge from rainfall estimated as per equation (1) is for the particular monsoon season.

\section{Estimation of normal recharge during monsoon season}

The rainfall recharge obtained by using equation (2) provides the recharge in any particular monsoon season for the associated monsoon season rainfall.

This estimate is to be normalised for the normal monsoon season rainfall which in turn is obtained as the average of the monsoon season rainfall for the recent 30 to 50 years. Let, $R_{i}$ be the rainfall recharge and $r_{i}$ be the associated rainfall.

The subscript $\mathrm{i}$ takes value 1 to $\mathrm{N}$ is usually at least 5 . The rainfall recharge, $R_{i}$ for the $i^{\text {th }}$ particular year is obtained as per the equation given below

$\mathrm{R}_{\mathrm{i}}=\mathrm{R}-\mathrm{R}_{\mathrm{gw}}-\mathrm{R}_{\mathrm{wc}}-\mathrm{R}_{\mathrm{t}}$

$\mathrm{R}_{\mathrm{i}}=\mathrm{h} \times \mathrm{S}_{\mathrm{y}} \times \mathrm{A}+\mathrm{DG}-\mathrm{R}_{\mathrm{gw}}-\mathrm{R}_{\mathrm{wc}}-\mathrm{R}_{\mathrm{t}}$ (3)

Where, $R_{i}$ is the rainfall recharge estimated for the $\mathrm{i}^{\text {th }}$ particular year, $\mathrm{H}$ is the rise in water table during monsoon season for the $i^{\text {th }}$ particular year, $S_{y}$ is the specific yield, $A$ is the area of assessment.

DG is the gross ground water draft during monsoon season for the $i^{\text {th }}$ particular year, $R_{\mathrm{gw}}$ is the recharge from groundwater irrigation in the monsoon season for the $\mathrm{i}^{\text {th }}$ particular year, $\mathrm{R}_{\mathrm{w}}$ is the recharge from water conservation structures and $R_{t}$ is the recharge from ponds.

Those pairs of $R_{i}$ and $r_{i}$ (associated rainfall) as obtained above which have $R_{i}$ as negative or nearly zero should be omitted, and only those pairs of data in which $R_{i}$ is greater than zero should be considered for further computations in the normalisation procedure. It is also likely that all the $\mathrm{R}_{\mathrm{i}}$ values as obtained above are consistently negative or nearly zero. In such a case, the water table fluctuation method should be dispensed with, and the normal rainfall recharge during the monsoon season should be estimated by the rainfall infiltration factor method based on rainfall infiltration factors.

After the pairs of data on $R_{i}$ and $r_{i}$ have been obtained as described above, a normalisation procedure is to be carried out for obtaining the rainfall recharge corresponding to the normal monsoon season rainfall.

Let $r$ (normal) be the normal monsoon season rainfall obtained on the basis of recent 30 to 50 years of monsoon season rainfall data.

The method is based on a linear relationship between recharge and rainfall of the form

$\mathrm{R}=\mathrm{ar},(4)$

Where, $\mathrm{R}$ is the rainfall recharge during monsoon season, $r$ is the monsoon season rainfall and a is a constant.

The computational procedure to be followed in the method is as given below

Each pair of $R_{i}$ and $r_{i}$ are used to obtain $\left[R_{r f}\right.$ (normal)] , as

$\left[\mathrm{R}_{\mathrm{rf}}(\text { normal })\right]_{\mathrm{i}}=\frac{\mathrm{R} \times \mathrm{r}(\text { normal })}{\mathrm{r}_{\mathrm{a}}}$

The normal monsoon season rainfall recharge, $\mathrm{R}_{\mathrm{rf}}$ (normal) is then

$\mathrm{R}_{\mathrm{rf}}($ normal $)=\frac{\sum_{\mathrm{i}=1}^{\mathrm{N}}\left[\mathrm{R}_{\mathrm{rf}} \text { (normal) }\right]_{i}}{\mathrm{~N}}$ 
Recharge from rainfall infiltration factor method

Recharge from rainfall in monsoon season by rainfall infiltration factor method based on rainfall infiltration factors which is given as

$\mathrm{R}_{\mathrm{rf}}=\mathrm{f} \times \mathrm{A} \times$ Normal rainfall in monsoon season (7)

Where, $\mathrm{f}$ is the rainfall infiltration factor (For Indo-Gangetic and Inland alluvial area, $\mathrm{f}=0.22$ ), and $\mathrm{A}$ is the area of computation for recharge

The same recharge factor may be used for both monsoon and non-monsoon rainfall, with the condition that the recharge due to nonmonsoon rainfall may be taken as zero, if the normal rainfall during the non-monsoon season is less than $10 \%$ of normal annual rainfall. In using the method based on the specified norms, recharge due to both monsoon and non-monsoon rainfall may be estimated for normal rainfall, based on recent 30 to 50 years of data. After the rainfall recharge for normal monsoon season rainfall using the water table fluctuation method has been estimated as described above, it is to be compared with the rainfall recharge estimated by rainfall infiltration factor method based on rainfall infiltration factors. For this a term percentage difference (PD) which is the difference between the two expressed as a percentage of the latter is computed as,

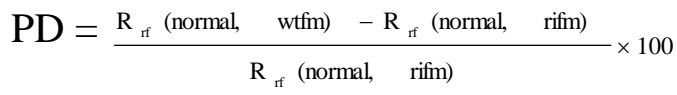

Where, $\mathrm{R}_{\mathrm{rf}}$ (normal, wlfm) is the rainfall recharge for normal monsoon season rainfall estimated by the water level fluctuation method, $\mathrm{R}_{\mathrm{rf}}$ (normal, rifm) is the rainfall recharge for normal monsoon season rainfall estimated by the rainfall infiltration factor method.
If $\mathrm{PD}$ is within $\pm 20 \%, \mathrm{R}_{\mathrm{rf}}$ (normal) $=\mathrm{R}_{\mathrm{rf}}$ (wlfm).

If $\mathrm{PD}$ is $<-20 \%, \mathrm{R}_{\mathrm{rf}}$ (normal) $=0.8 \times \mathrm{R}_{\mathrm{rf}}$ (rifm).

If $\mathrm{PD}$ is $>20 \%, \mathrm{R}_{\mathrm{rf}}($ normal $)=1.2 \times \mathrm{R}_{\mathrm{rf}}(\mathrm{rifm})$.

The total recharge during the monsoon season for normal monsoon season rainfall condition is finally obtained as,

$\mathrm{R}($ normal $)=\mathrm{R}_{\mathrm{rf}}($ normal $)+\mathrm{R}_{\mathrm{gw}}+\mathrm{R}_{\mathrm{wc}}+\mathrm{R}_{\mathrm{t}}(9)$

Where, $\mathrm{R}$ (normal) is the total recharge during monsoon season, $\mathrm{R}_{\mathrm{rf}}$ (normal) is the rainfall recharge during monsoon season for normal monsoon season rainfall, $\mathrm{R}_{\mathrm{gw}}$ is the recharge from ground water irrigation in the monsoon season for the year of assessment, $R_{\mathrm{wc}}$ is the recharge from water conservation structures in the monsoon season for the year of assessment and $R_{t}$ is the recharge from tanks/ponds in the monsoon season for the year of assessment.

\section{Estimation of normal recharge during non monsoon season}

The recharge from rainfall during the nonmonsoon season may be estimated based on the rainfall infiltration factor method, provided the normal rainfall in the nonmonsoon season is greater than $10 \%$ of the normal annual rainfall.

If the rainfall is less than this threshold value, the recharge due to rainfall in the nonmonsoon season may be taken as zero. Recharge during the non-monsoon season from other sources, namely from ground water irrigation $\left(\mathrm{R}_{\mathrm{gw}}\right)$, tanks $\left(\mathrm{R}_{\mathrm{t}}\right)$ and from water conservation structures $\left(R_{\mathrm{wc}}\right)$ are to be estimated from the norms recommended in GEC-1997 or values obtained through field studies. 


\section{Total annual ground water recharge}

The total annual ground water recharge of the assessment unit is the sum-total of monsoon and non monsoon recharge.

Annual recharge $=$ Recharge during monsoon + Recharge during non-monsoon.

\section{Net ground water availability}

It is the difference of annual ground water recharge and natural discharge during nonmonsoon season.

An allowance is kept for natural discharge in the non-monsoon season by deducting $5 \%$ of total annual ground water recharge, of water table fluctuation method is employed to compute rainfall recharge during monsoon season and $10 \%$ of the annual ground water recharge if rainfall infiltration method is employed.

The balance ground water available accounts for existing ground water withdrawal for various uses and potential future development.

Net ground water availability = Annual ground water recharge - Natural discharge during non-monsoon season

\section{Categorization of district}

The assessment units are categorized for ground water development based on status of ground water utilisation and water level drain. The following four categories are - safe areas, which have ground water potential for development, semi critical areas, where cautious ground water development is recommended, critical areas and over exploited areas where there should be intensive monitoring and evaluation and future ground water development be linked with water conservation measures.

$$
\begin{aligned}
& \text { Ground water development (\%) = } \\
& \frac{\text { Existing gross } \text { ground }}{\text { water draft for all uses }} \times 100
\end{aligned}
$$

Criteria for categorization of assessment units

Stage of ground water development $\leq 70 \%$ comes under safe category, $\leq 70$ and $\leq 90 \%$ under semi critical with long term decline, $\leq 90$ and $\leq 100 \%$ under critical and $>100 \%$ comes under over exploited category.

\section{Results and Discussion}

\section{Water table fluctuation}

The data of pre and post monsoon water level of Patna and Gaya districts for eleven years (1998-2008) where collected from Directorate of ground Water, Patna and based upon this water table fluctuation was calculated. The long term water table fluctuation in Patna district varies from -0.50 to $3.36 \mathrm{~m}$ with an average value of $1.87 \mathrm{~m}$. the data shows that water table fluctuation was lowest in the year 2005 and highest in the year 1998.

The lowest value of water table fluctuation in the year 2005 is due to very less amount of rainfall in 2005 (Fig. 1). Lower amount of rainfall has also speeded up the ground water pumpages for growing Kharif crop. The long term (1998-2008) water table fluctuation in Gaya district varied from 0.04 to $2.03 \mathrm{~m}$ with an average value of $0.76 \mathrm{~m}$.

\section{Computation of rainfall data $\left(r_{a}\right)$}

Annual rainfall data for eleven year were computed from monthly rainfall data, whereas the average monsoon rainfall (June to Sept.) of Patna and Gaya districts were calculated from the data of monthly rainfall, which is $818.12 \mathrm{~mm}$ and $847.4 \mathrm{~mm}$ respectively. The average annual rainfall for nine years (1998- 
2006) of Patna and Gaya districts are displayed in figure 2 .

\section{Computation of normal rainfall data( $r$ (normal)}

The normal rainfall data of Patna and Gaya districts are $970.53 \mathrm{~mm}$ and $961.83 \mathrm{~mm}$ respectively which is the average value of thirty years (1974-2004) rainfall data.

\section{Computation of gross ground water draft}

The total annual ground water draft of Patna and Gaya districts were 40152.6 ha-m and
37309.2 ha-m respectively, which was computed by unit draft and different types of ground water extraction structures (Dug wells, Shallow tube wells and Deep tube wells).

\section{Computation of recharge from return flow ground water irrigation $\left(\mathbf{R}_{\mathbf{g w}}\right)$}

Recharge from return flow from ground water irrigation $\left(\mathrm{R}_{\mathrm{gw}}\right)$ of Patna and Gaya districts during monsoon season were 6022.89 ha-m and 5596.38 ha-m respectively, which is the $30 \%$ of the ground water draft during monsoon season (under norms of GEC-97).

Table.1 Ground water resource and development potential of Patna and Gaya districts of Bihar (ha-m)

\begin{tabular}{|c|l|c|c|}
\hline S. No. & \multicolumn{1}{|c|}{ Component } & \multicolumn{2}{|c|}{ District } \\
\cline { 2 - 3 } & \multicolumn{1}{|c|}{ Patna } & Gaya \\
\hline 1. & Recharge from rainfall during monsoon season & 68517.79 & 74213.26 \\
\hline 2. & Recharge from other sources during monsoon season & 6298.525 & 5868.82 \\
\hline 3. & Recharge from rainfall during non-monsoon season & 10636.99 & 12526.88 \\
\hline 4. & Recharge from other sources during non-monsoon season & 6471.05 & 6039.34 \\
\hline 5. & Total annual ground water recharge & 91924.36 & 98648.29 \\
\hline 6. & Natural discharge during non-monsoon season & 9192.43 & 9864.83 \\
\hline 7. & Net ground water availability & 82731.93 & 88783.47 \\
\hline 8. & Existing ground water draft for irrigation & 40152.6 & 37309.2 \\
\hline 9. & $\begin{array}{l}\text { Existing ground water draft for domestic and industrial water } \\
\text { supply }\end{array}$ & 7176 & 5831 \\
\hline 10. & Existing gross ground water draft for all uses & 47328.6 & 43140.2 \\
\hline 11. & $\begin{array}{l}\text { Net ground water availability for future irrigation } \\
\text { development }\end{array}$ & 35403.33 & 45643.27 \\
\hline 12. & Stage of ground water development (\%) & 57.20 & 48.59 \\
\hline 13. & Category & Safe & Safe \\
\hline
\end{tabular}

Fig.1 Average water table fluctuation (h)

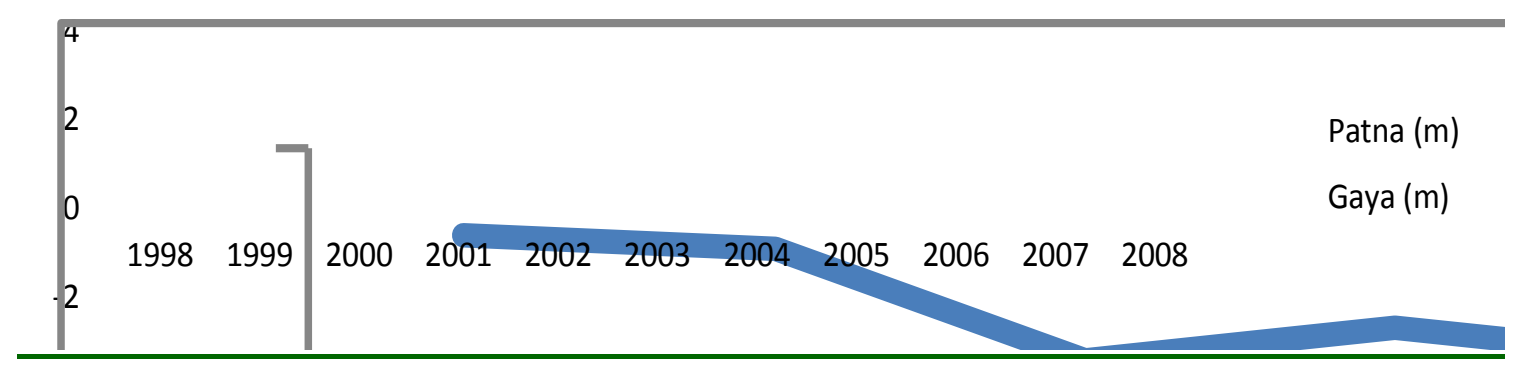


Fig.2 Average annual rainfall of Patna and Gaya districts

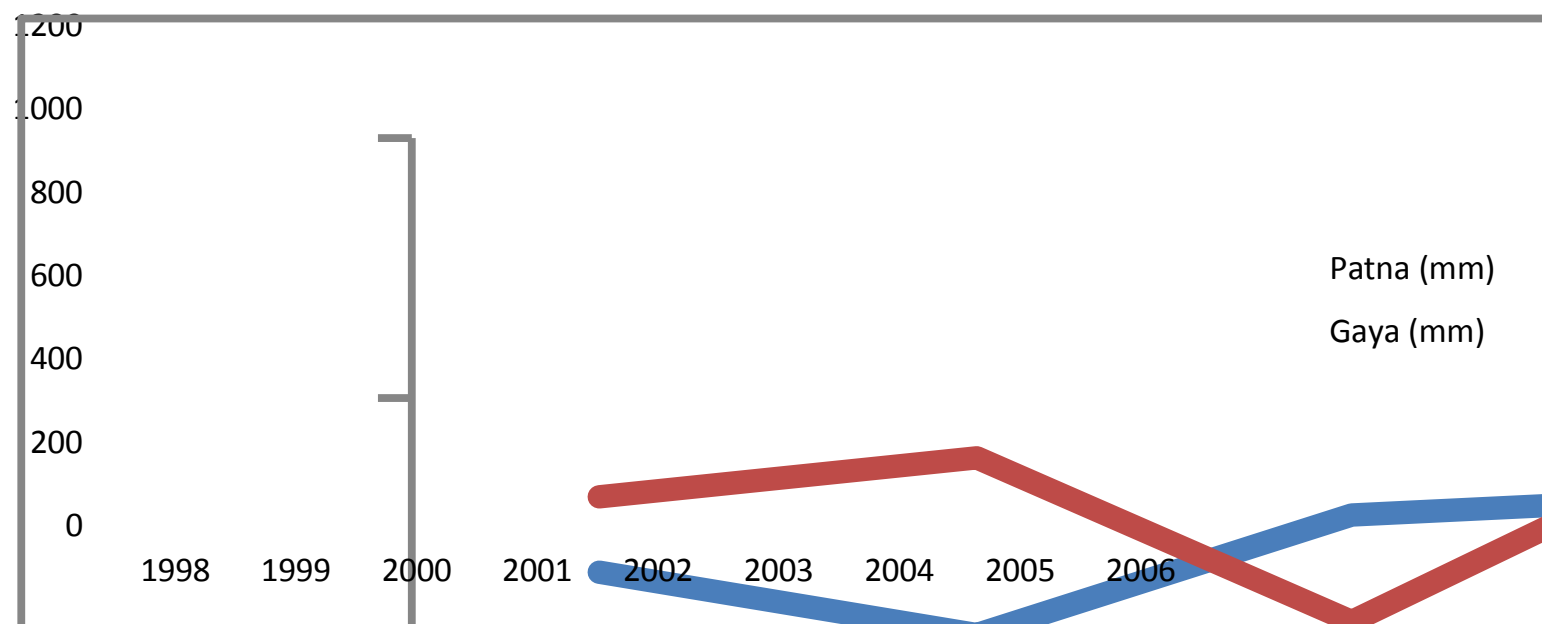

Fig.3 Rainfall recharge during monsoon season in Patna district

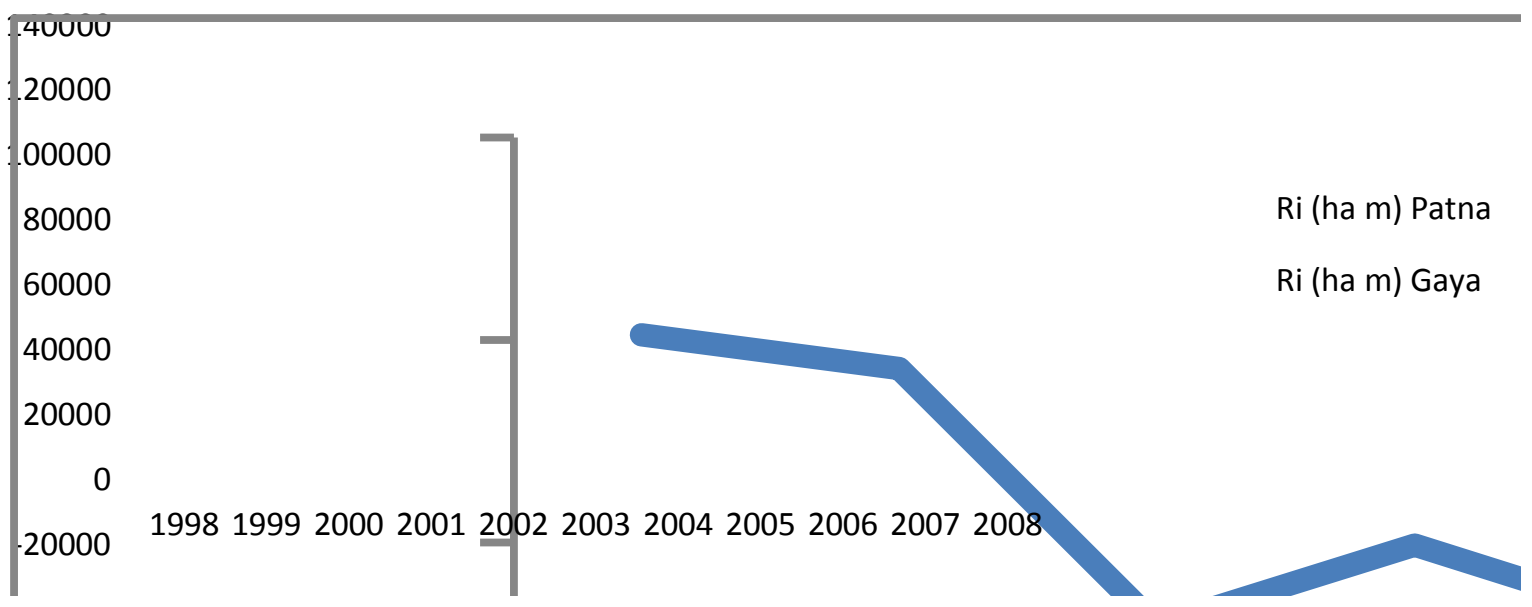

Fig.4 Normal monsoon season recharge

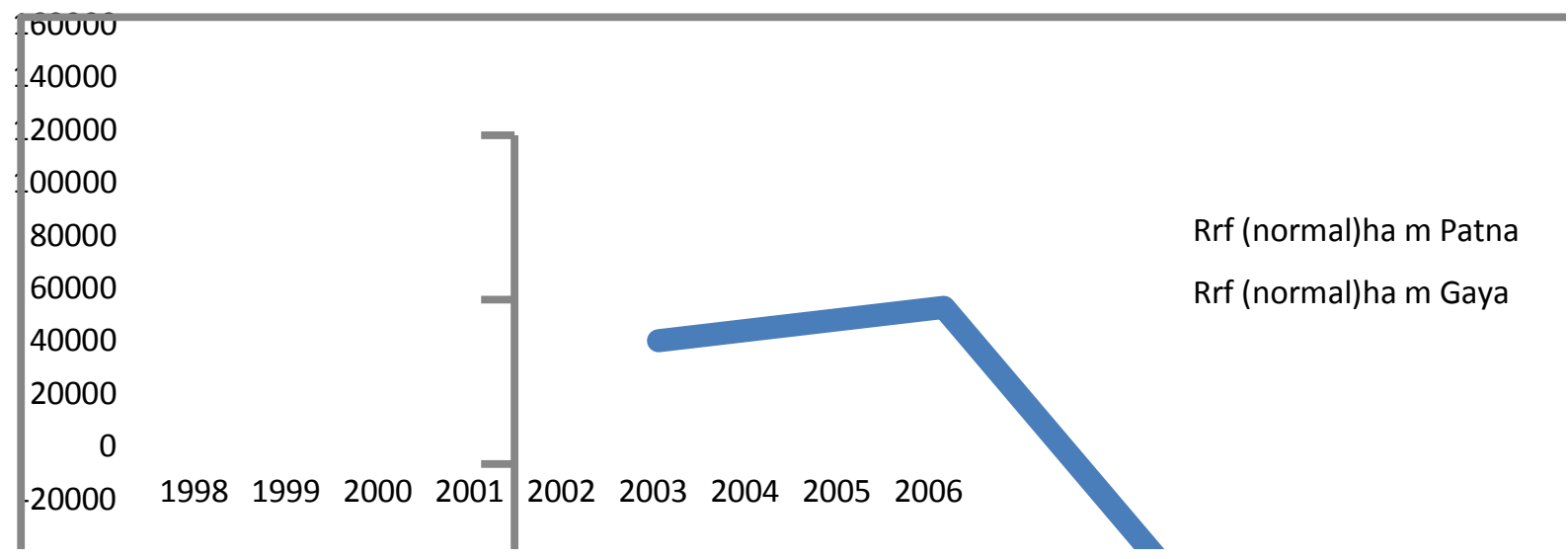




\section{Computation of recharge from ponds $\left(\mathbf{R}_{t}\right)$}

Recharge from ponds of Patna and Gaya districts were 275.635 ha-m and 272.44 ha-m respectively.

\section{Computation of rainfall recharge during monsoon season}

Rainfall recharge during monsoon season for particular year (1998-2008) was calculated from water table fluctuation method.

Rainfall recharge during monsoon season for particular year of Patna district varied from 2214.09 ha-m to 120369.07 ha-m, thereby indicating that variation was found to be higher in the year 1998 and lower in the year 2005 figure 3. The lowest rainfall recharge in the year 2005 is due to very low rainfall (Fig. 2) in the year 2005 .

Rainfall recharge during monsoon season for particular year of Gaya district varied from 16965.62 ha-m to 113569.684 ha-m, thereby indicating that variation was found to be higher in the year 2008 and lower in the year 2005.

\section{Normalisation of rainfall recharge during monsoon season}

The normal monsoon season recharge during period nine years of Patna district varied from-6651.12 ha-m to 139135.08 ha-m, thereby indicating that variation was found to be higher in the year 1999 and lower in the year 2005. The normal monsoon season rainfall recharge of Patna district is 81782.79 ha-m which is the average value of normal monsoon season rainfall recharge of particular year from 1998 to 2006 by using water table fluctuation method (Fig. 4).

The normal monsoon season recharge during period nine years of Gaya district varied from
24625.58 ha-m to 81270.96 ha-m, thereby indicated that variation was found to be higher in the year 2000 and lower in the year 2006.The normal monsoon season recharge of Gaya district is 54275.23 ha-m.

\section{Rainfall recharge from RIF method}

The rainfall recharge during monsoon season in Patna district and Gaya district are estimated as 57098.17 ha-m and 92766.57 ha$\mathrm{m}$ respectively. The percentage difference (PD) for Patna and Gaya district are $43.23 \%$ and $-41.4 \%$ respectively.

The rainfall recharge during monsoon season for normal monsoon season rainfall is 68517.79 ha-m for Patna district and 74213.26 ha-m for Gaya district.

\section{Total monsoon recharge}

The total recharge during monsoon season of Patna district and Gaya district are 74816.32 ha-m. and 80082.08 ha-m. respectively.

\section{Computation of normal recharge during non-monsoon season}

The recharge from rainfall during the nonmonsoon season of Patna and Gaya district are 10636.99 ha-m and 12526.88 ha-m respectively.

Recharge during the non-monsoon season from other sources, namely from ground water irrigation $\left(\mathrm{R}_{\mathrm{gw}}\right)$ is 6022.89 ha-m for Patna and 5596.38 ha-m for Gaya district, ponds $\left(\mathrm{R}_{\mathrm{t}}\right)$ is 448.16 ha-m for Patna and 442.96 ha-m for gaya district and from water conservation structures $\left(\mathrm{R}_{\mathrm{wc}}\right)$ were estimated from the norms recommended in GEC-97. Thus, the total recharge in the non-monsoon season in Patna and Gaya district are 17108.03 ha-m and 18566.22 ha-m respectively. 


\section{Computation of total annual recharge}

The total annual ground water recharge is 91924.36 ha-m for Patna district and 98648.29 ha-m for Gaya district.

\section{Ground water resources}

The details of various components of ground water recharge in Patna and Gaya district are depicted in Table 1. Data shows that total annual ground water recharge is 91924.33 ha$\mathrm{m}$ and 98648.29 ha-m for Patna and Gaya district respectively. The existing ground water draft for irrigation is 40152.6 ha-m for Patna district and 37309.2 ha-m for Gaya district. The ground water draft for all uses is 47328.6 ha-m for Patna district and 43140.2 ha-m for Gaya district. The net annual replenishable ground water resource is worked out to be 82731.93 ha-m for Patna district and 88783.47 ha-m for Gaya district. The net annual ground water available for future irrigation development is 35403.325 ha-m for Patna district and 45643.27 ha-m for Gaya district. The stage of ground water development is $57.20 \%$ for Patna district and $48.59 \%$ for Gaya district. According to definitions used by CGWB both Patna Gaya district falls in safe category.

\section{References}

Chatterjee, R. and Purohit, R.R. (2009). Estimation of replenishable ground water resources of India and their status of utilization. Current-Science. 96(12): 1581-1591.

Chatterjee, R., Gupta, B.K., Mohiddin, S.K., Singh, P.N., Shekhar, S. and Purohit, R. (2009). Dynamic ground water resource of national capital territory, Delhi assessment, development and management options. EnvironmentalEarth-Sciences. 59(3): 669-686.

Government of India (2006). Dynamic ground water resources of India as on March 2004. New Delhi Ministry of Water Resources, Government of India. pp (187).

Government of India (2007). Report of the expert group on "Groundwater management and ownership" submitted to Planning Commission, September 2007. Government of India, Planning Commission, Yojana Bhavan, Parliamentary Street, New Delhi. 61 pages

Ground water resource estimation methodology (1997). Report of the Ground Water Resource Estimation Committee, Central Ground Water Board Ministry of Water Resources (Govt. of India). New Delhi, June 1997.

Kaushal, M.P., Singh, P. and Sondhu, S.K. (1997). Ground water potential of upper Bari Doab Canal tract of Panjab. J. Res. Punjab Agric. Univ. 34(3): 328-336.

Kumar, C.P. (1989). Assessment of ground water potential. Proceedings International Seminar on Development and Management of Ground Water Resources. University of Roorkee.

Mane, M.S., Singh, D.K., Bhattacharya, A.K. and Singh, A.K. (2008). Assessment of ground water potential for irrigation. International-Journal-of-AgriculturalEngineering. 1(2): 74-80.

Mathur, B.S., Singhal, B.B.S. and Venugopal, T.V. (1979). Estimation of ground water recharge from rainfall in hard rocks of Karanja basin. Proceedings International Seminar on Development and Management of Ground Water Resources. University of Roorkee, Roorkee, Nov. 5-20, pp. 18-24.

Mills, A.C. and Shata, A. (1989). Ground water assessment of Sinai, Egypt. Ground Water. 27(6): 793-801.

Prasad, R.K. (1992). Estimation of draft norm for assessment of ground water withdrawal. Proceedings $16^{\text {th }}$ ICID 
European Regional Conference Vol-1Drought Phenomenon. 291-302.

Rao, K. (1970). Hydrometrological aspects of estimating ground water potential. Seminar on ground water potential in hard rock areas. Banglore Geol. Soc. Ind. 1(1):1-18.

Singh, A.K. (2005). Studies on ground water recharge estimation of selected blocks of Muzaffarpur district. B. Tech. Thesis, C.A.E. Pusa.

Sridharan, K., Manavalan, P. and Ramanjaneyulu, M. (2002). An integrated approach to ground water resource assessment. Proceedings of the international ground water conference on sustainable development and management of groundwater resources in semi-arid region with special reference to hard rocks, Dindidul, Tamil-Nadu, India, 20-20 February, 2002; 153-160.

Sudhishri, S., Patnaik, U.S. and Dass, A. (2007). Hydrological study and water resources assessment in Kokriguda watershed of Orissa for sustainable water management. Indian Journal of Soil Conservation. 35(2): 103-107.

World Bank (1998). India Water resources management sector review, New Delhi Rural development unit South Asia Region.

\section{How to cite this article:}

Amit Kumar, Shikha Anand, Manish Kumar and Ravish Chandra. 2017. Groundwater Assessment: A Case Study in Patna and Gaya District of Bihar, India. Int.J.Curr.Microbiol.App.Sci. 6(12): 184-195. doi: https://doi.org/10.20546/ijcmas.2017.612.024 